\title{
WHAT IS (POST)QUALITATIVE RESEARCH?
}

\author{
L. Le Grange \\ Department of Curriculum Studies \\ Stellenbosch University \\ Stellenbosch, South Africa \\ e-mail: llg@sun.ac.za
}

\section{ABSTRACT}

The (post)human turn has ushered in new ways of doing inquiry. (Post)humanism is the catalyst for news ways of thinking and doing research under an umbrella term called (post)qualitative research. In this article I discuss the contextual and philosophical dimensions that gave rise to (post)qualitative research. I outline some emerging characteristics of (post)qualitative research and discuss its relevance to South Africa. I suggest that (post)qualitative research informed by both (post)human theories and indigenous philosophies could open up new ways of doing research in the country, including research with water and land. I do not provide a set of answers in the article, but open up alternative ways of thinking and doing inquiry in the Anthropocene and in a context of ongoing decolonial conversations.

Keywords: Anthropocene, (post)qualitative, (post)human, research ethics, Ubuntu

\section{INTRODUCTION}

A survey of articles published in the SAJHE show that empirical research reported in the journal is dominated by traditional quantitative and qualitative studies. My reference to quantitative and qualitative studies relates to both the literal and derivative distinctions between quantitative and qualitative research. According to Howe $(1992,237)$ the literal distinction is concerned with data production, research design and analysis (the techniques and procedures of research). In others words, it relates to the types of data that are produced by research methods. Data in the form of numbers (quantitative indices) are quantitative and in the form of words (narratives) or visual images are qualitative. A research method/technique such as an interview or questionnaire could therefore be either a quantitative or qualitative method depending on the type of data it produces (Le Grange 2000). Moreover, the literal distinction also makes possible the mixing of methods/techniques that produce quantitative and qualitative data, as is evident in a more recent development called mixed-methods research, driven by a pragmatic interest.

According to Howe $(1992,237)$, the derivative distinction has to do with the 
epistemological assumptions, which underlie different research approaches. I would add ontological and axiological distinctions as well. Epistemologically and ontologically the quantitative-qualitative distinction has its roots in the positivist-interpretivist split. This split arose when social scientists challenged the idea that the social sciences should be modelled on the natural sciences (Le Grange 2000). As Giddens (1976, 13) writes, "those social scientists who still wait for a Newton are not only waiting for a train that won't arrive, they're in the wrong station altogether". According to Giddens $(1976,55)$, understanding within the natural sciences occurs by the method of causal explanation from the outside (erklären) whereas in the social sciences inquiry is based on understanding (verstehen) humanity through and empathetic identification with the other, a grasping of their subjective experience. The upshot of this is that the same style of explanation, for say, electrons in motion cannot be used for human actions, which have appeal to beliefs, desires, and goal directedness. In other words, in order to understand human actions an intentional stance is required. Howe (1992) avers that such an intentional stance excludes the natural sciences approach altogether. He points out that in this way the natural sciences has come to be identified with positivism and the intentional stance with interpretivism. Consequently, "positivism and interpretivism [are deemed to be] incompatible by virtue of various familiar dualisms, such as objectivity versus subjectivity, fixed categories versus emergent categories, the outsider's perspective versus the insider's perspective, a static reality versus a fluid reality, and explanation versus understanding" (Howe 1992, 239). This incompatibility was the basis for what became known as the quantitativequalitative divide during a period of robust contestation in educational research (particularly in the USA), which Gage $(1989,135)$ characterised as "the paradigm wars". Over time, qualitative research expanded to also incorporate research informed by critical theories and poststructuralist thought. In the USA, in particular it became an umbrella term for an array of methodologies which arose after the hegemony of positivism had been challenged. In documenting the history of qualitative research in the USA, Denzin and Lincoln (2008, 20-27) outline eight moments of qualitative research, which I shall paraphrase:

1. The traditional period (1900s to 1950) - qualitative researchers wrote "objective" colonising accounts of field experiences that reflected positivism.

2. The modernist phase (1950 to 1970) - built on canonical work of the traditional period. The modernist ethnographer and sociological participant observer conducted rigorous studies on social processes such as deviance and social control in the classroom and society. A new generation of researchers emerged who encountered new interpretive theories (ethnomethodology, phenomenology, critical theory, feminism). 
3. Blurred genres (1970 to 1986) - a moment in which the boundaries between the social sciences and the humanities had become blurred. The social sciences turned to the humanities for models, theories and methods of analysis. It drew on semiotics and hermeneutics, for example.

4. The crisis of representation (1986 to 1990) - the moment when qualitative researchers realised that they can no longer directly capture lived experience, but that lived experience is created in social texts written by the researcher.

5. The postmodern (1990-1995) - a period of experimental ethnographic writing, writing as different tales of the field.

6. Postexperimental inquiry (1995-2000) - a moment of ethnographic alternatives; novel forms expressing lived experience through representations that were literary, poetic, autobiographical, visual, performative, and so forth.

7. The methodological contested present (2000-2004) - a period of tension and conflict as a consequence of moment 7 .

8. The fractured future (2005-) - a moment when scholars in the USA, in particular are confronting the methodological backlash with "Bush science" and the evidence-based research movement.

In practice, many qualitative research projects will of course not simply align with only one of these moments and will inevitably draw on what was produced in two or more moments. What Denzin and Lincoln's moments do is to capture some of the key transformations in social/educational research, which fall under the umbrella of qualitative research. (Post)qualitative research marks a break from the different genres of qualitative research mentioned and is informed by a significant ontolological (re)turn in social theory - the (re)turn to realism(s). The (re)turn to realism(s) is associated with a contemporary condition called the (post)human condition. Next I shall discuss this condition and a (re)turn to realism(s). This will be followed by a discussion on (post)qualitative research. Thereafter, I shall discuss the relevance of (post)qualitative ${ }^{1}$ research for South Africa. I end with some parting thoughts.

\section{A (RE)TURN TO REALISM(S)}

Le Grange (2018a, 882) avers that planet Earth is changing in two significant ways. Firstly, the planet is on the brink of ecological disaster, evidenced by ongoing human actions that are decimating plants and animals, polluting oceans and rivers, producing atmospheric change, creating growing inequalities, and so forth. Secondly, the growth of new technologies is irrevocably changing the planet to the extent that humans have become interconnected with 
technologies, introducing "a qualitative shift in our thinking about what exactly is the basic unit of common reference for our species" (Braidotti 2013, 2). The first planetary change has made scientists posit a new geological epoch, the Anthropocene. ${ }^{2}$ The second planetary change (together with the first planetary change) has produced a historical moment referred to as a (post)human condition. This condition relates to the fact that humans have reached a point where as a species it is not only able to manipulate and control all of life but also has the capability to destroying it. Human arrogance or self-esteem has reached its zenith. Yet at the same time the human body (or its parts) is being commodified and the genetic code is now capital. Moreover, non-human objects created by humans threaten to destroy all life including that of humans - objects such drones, tools of biological warfare, the potential of nanotechnology to produce self-reproducing molecular machines called ecophages, etc. In a technologically mediated world the boundary between human and machine is becoming blurred. The predicament that this produces is how we negotiate the potential negative effects of new technologies without becoming technophobic - how do we resist and at the same time embrace new technologies.

Among other developments, this historical moment is witnessing a (re)turn to realisms: a return to critical realism; a turn to speculative realism and matter-realism (new materialism) because existing philosophies (phenomenology, critical theory and poststructuralism) are no longer adequate for responding to current challenges. As Bryant, Srnicek and Harman 2011,3) write:

"In the face of the ecological crisis, the forward march of neuroscience, the increasingly splintered interpretations of basic physics, and the ongoing breach of the divide between human and machine, there is a growing sense that previous philosophies are incapable of confronting these events."

Moreover, Johnson $(2013,5)$ states that, "the naturalization of capitalism has made the epistemic limits of critical theory ever more apparent". He argues that the theories that challenged the limits of the social continuum, have ironically succumb to the very economic analysis they were meant to confront.

A (re)turn to speculative realism, new materialisms (matter-realism) and critical realism is a response to the perceived limits of linguistic (post)structuralisms and other anthropocentric philosophies. All the realisms mentioned are opposed to what is referred to as naïve realism/materialism - the idea that an external observer is the locus from which the entire world can be grasped. Speculative and new materialisms are recent responses to the now "tiresome 'Linguistic Turn"” (Bryant et al. 2011, 1). Speculative realism denotes a range of thought but put simply, it is a philosophy that signifies a return to speculating the nature of reality 
independently of human thought and holds that continental philosophy (phenomenology, structuralism, post-structuralism, deconstruction and postmodernism) has descended into an anti-realist stance in the form of what Meillassoux $(2008,5)$ terms "correlationism". Put simply, correlationalism means that reality appears only as the correlate of human thought - the limit of correlationalism is why conventional continental philosophy might be considered to be anthropocentric.

New materialism represents an interdisciplinary field of inquiry produced by a community of feminist scholars. It is marked by a return to realism because post-war discourses of structuralism and poststructuralism have become more or less exhausted. New materialism questions the privileging of subjectivity and representation and according to Braidotti (2012, 171) replaces textual and other deconstruction with an ontology of modulated presence. New materialists find inspiration in thinking with Deleuze, and in particular the late Deleuze who collaborated with Guattari in placing the human on an immanent plane, thereby stripping it of its ontological privilege. Moreover, new materialists hold that all matter (including organic matter) has agential capacities. This idea is depicted in Barad's $(2007,132)$ concept of "agential realism". About the idea that nature is agentic, Gough $(2016,52)$ writes: “... its acts, and those actions have consequences for both the human and nonhuman world". Another important contention of new materialism is that ontology, epistemology and ethics are inseparable, captured in Barad's $(2007,409)$ neologism, "ethico-onto-epistemology".

The obvious implication of the (re)turn to realism(s) is that the binary between the natural and the human and social sciences becomes blurred - therefore new materialism is appropriately described as an interdisciplinary field. The ontological turn associated with new realisms/materialisms invites a rethinking of both the natural sciences and the human and social sciences and supplants Giddens's (1976) distinction between the two that was noted earlier.

\section{WHAT IS (POST)QUALITATIVE RESEARCH?}

Asking the question, what is (post)qualitative research is not aimed at providing a definition or to provide clarity on a new practice. My response to the question, is to provide some context for why (post)qualitative is being invoked at this historical moment, what emerging insights we might glean from what has been written about it and what opportunities such insights might open up for new ways of doing inquiry.

The reasons for the emergence of discourses on (post)qualitative research are multiple. One reason for its invocation in the USA is a space that qualitative researchers (particularly educational researchers) now have, "after" a decade of Scientific Research in Education (SRE), "to ask what comes next for qualitative research" (Lather and St. Pierre 2013). Or perhaps, what 
comes next after qualitative research had been constrained by SRE. By SRE, scholars in the USA refer to a report (Committee on Scientific Principles for Education Research 2002) which placed constraints on qualitative research. Following the publication of the SRE report, qualitative researchers who applied to the National Research Council in the USA for research grants were coerced into completing quantitative type templates that Brady and Collier (2004, 15) pronounced as an exercise in "quantitative imperialism". Lather (2013) avers that such efforts to discipline qualitative research via rubrics and standards need to be understood in the context of the transition from Keynesian liberalism to neoliberal governmentality. The effect of this transition on research was the repositivisation of science. The upshot of the latter was the thwarting of an array of qualitative studies associated with turns in social theory such as "linguistic, structural, critical, deconstructive, rhetorical, cultural, narrative, historical, ethnographic, postmodern, ethical, visual, pragmatic ..., material, affective" (Lather 2013, 634), and so forth. ${ }^{3}$

(Post)qualitative research is therefore that which comes after SRE - after Denzin and Lincoln's (2008) eighth moment of qualitative research. But, it is also research that takes place with/in a historical moment, associated with the (post)human condition that I discussed above. St. Pierre (2011) avers that (post)humanism remains the catalyst for (post)qualitative research. So, what insights might we glean from an emerging body of literature on (post)qualitative research. Firstly, (post)qualitative research might be viewed as a "methodology-to-come" (Lather 2013, 635). This means that it cannot be neatly described in textbooks and there is no methodological guide that can be learned in a trouble-free manner. Secondly, (post)qualitative research is not a new paradigm in the sense that it is a totalising methodology. It is nontotalising, and as Lather $(2013,635)$ calls it, "a thousand tiny methodologies" when thinking with Deleuze and Guattari (1987). Thirdly, (post)qualitative research decentres knowledge in the sense that it questions the privileging of knowledge in research. Following Descartes's invocation of cogito (the knowing subject) more than 300 years ago, knowledge has been the central focus of research. This of course does not mean that knowledge was uncontested in qualitative research work. ${ }^{4}$ Critiques of knowledge have resulted in the recovery of knowledges of the oppressed, portrayed in descriptions such as "situated knowledges", "standpoint epistemologies" and "subjugated knowledges" (St. Pierre 2013, 648). The critiques of the epistemologies mentioned and the recovery of knowledges of the oppressed are important, but also reflect the continuing privileging of knowledge in qualitative research. (Post)qualitative research sees researchers questioning why knowledge should be the point of departure in inquiry, decentres knowledge and embraces the inseparability of ethics, ontology and knowledge, as depicted in Barad's (2007, 409) coinage, “ethico-onto-epistemology". 
(Post)qualitative research therefore is post-Cartesian.

Fourthly, (post)qualitative research involves critiquing representational logic. St. Pierre (2013) points out that representational schema assume two things: that there is a primary, originary reality to be found; and that language is able to accurately represent such a reality. Critiques of representational logic have been performed by poststructuralist scholars; and (post)qualitative research will presumably expand on such critiques by asking what the role of language is as we (re)turn to new realisms/materialisms and importantly, whether we can escape "representational logic and the language/material binary" (St. Pierre 2013, 650). Barad's (2007) neologism of "intra-action", which portrays the imbrication of meaning and matter, might be helpful here so that language is not understood simply in discursive terms, but materially too that language is the product of material flows. Moreover, that language is not stable as is the case with all modes of life. As Le Grange (2018b, 45) writes: “All things, even physical objects such as desks and computers are in-becoming - rocks, human beings as well as systems of thought and language do not have fixity but are always changing". Given its critique of representational logic (post)qualitative research might find resonances with an emerging field called non-representational research. Ingold (2015, vii) calls non-representational research "a correspondence, in the sense of not coming up with some exact match or simulacrum for what we find in the things and happenings going on around us, but of answering them with interventions, questions, and responses of our own" (emphasis in the original).

Fifthly, in (post)qualitative research subjectivity becomes ecological or imperceptible. Le Grange $(2016,34)$ depicts this reconfigured sense of subjectivity as follows:

"The subject of [(post)qualitative research] ... is not an atomised individual but is ecological; embedded in the material flows of the earth/cosmos, constitutive of these flows, making the subject imperceptible. [Research] ... [is] not performed on the earth but bent by the earth."

(Post)qualitative research therefore is post-anthropocentric. This reconfigured subject raises critical questions that (post)qualitative inquiries might need to engage, which Lather and St. Pierre $(2013,630)$ so meaningfully articulate:

"[E]ntanglement makes all the categories of humanist qualitative research problematic. For example, how do we determine the 'object of our knowledge' - the 'problem' we want to study in assemblage? Can we disconnect ourselves from the mangle somehow (Self) and then carefully disconnect some other small piece of the mangle (Other) long enough to study it? ... How do we think 'a research problem' in the imbrication of an agentic assemblage of diverse elements that are constantly intra-acting, never stable, never the same?" 
Sixthly, (post)qualitative research invites us to think differently with data and data analysis. Data are not something out there that we gather or collect and is not isolated from self. As Lather $(2013,639)$ writes:

\begin{abstract}
“'Making love to' one's data becomes thinkable as a kind of ethics, something quite different from 'better or smarter', something more akin to the in-between places of pleasure and pain. Struggling with and against, becoming more and other, 'in a field of production of desire', analysis moves way beyond interpretation."
\end{abstract}

With respect to data analysis (post)qualitative inquiry bids us to reimagine data analysis so that the banality of coding and categorising that characterise conventional qualitative research could be overcome. It involves resisting the "habitual reading of data" (Lather 2013, 639) that is akin to what Deleuze $(2000,97)$ termed "violence to thought". In Lather's (2013) account of an essay of Swedish poststructuralist Hillevi Lenz-Taguchi in which she theorises Deleuze and Guattari's "molecular girl" one gains a sense of how post-qualitative researchers could work differently with data. Lather $(2013,639)$ writes:

\begin{abstract}
"Escaping binaries into continuums and multiplicities, new events of thinking were materialized; data could be relived from differing subject positions; thinking became creation as researchers were transformed into creative thinkers in assemblage with one another in a state of virtuality. Here being used by thought has its pleasures, zigzagging through networks of 'difference' in a non-hierarchical manner."
\end{abstract}

Seventhly, (post)qualitative research recognises that method is performative. In other words, we can choose methods which are transformative - methods that make possible the transformation of the world. In other words, the methods of (post)qualitative research unfold through intra-actions with the world. Lastly, ${ }^{5}$ ethics in (post)qualitative research is an immanent ethics - it is not pre-ordinate, or externally imposed as is the case with ethical clearance regimes that have become commonplace in universities. Le Grange $(2017,102)$ points out that an immanent ethics is when, "the creative power of life functions as an ethical principle in two senses: first, it opposes any transcendent values and follows immanent rules implicit in the modes of existence; second the creative power of life dissolves the model of subjectivity and at the same time the powers of subjectification". He goes on to argue that such a view of ethics creates the conditions for the "ethics of becoming-imperceptible". About becomingimperceptible Le Grange $(2017,102)$ writes:

"The disappearance of the individual self that characterizes becoming-imperceptible overcomes the problem of correlationism .... In becoming-imperceptible the cosmos or the earth is not reduced 
to human thought, but human thought is instead bent by the earth/cosmos. The 'human' does not simply inhabit the world/earth but is inhabited by it."

(Post)qualitative research informed by an immanent ethics opens up pathways for all those involved in research to increase their powers of acting, to express their generosity, and to love the world (all of life) - it is an invitation to dance (just do) (Braidotti 2006, 259). It is when the power within us is suppressed/colonised by what is external to life's creative power that we see the erosion of Guattari's (2001) three ecologies, mental, social and environment. Smith (2012, 285) writes about an immanent ethics in the following way:

“The fundamental question of ethics is not 'What must I do?' (the question of morality) but rather 'What can I do?' Given my degree of power, what are my capabilities and capacities? How can I come into active possession of my power? How can I go to the limit of what I 'can do'."

As a methodology-in-becoming there can be no closure to (post)qualitative research. Much more can be proliferated on what (post)qualitative research could become. But, what we can garner from its unfolding is that it invites as to think, feel and act differently and that a different future is to be found in a life of experimentation in intra-action with the real and that the transformative potential of (post)qualitative research makes it relevant to engaging challenges of a contemporary world. It is with this in mind that I turn to a brief discussion on the relevance of (post)qualitative research to South Africa.

\section{THE RELEVANCE OF (POST)QUALITATIVE RESEARCH TO SOUTH AFRICA}

I wish to suggest at least three reasons why post-qualitative research could be pertinent to South Africa. Firstly, emerging approaches such as (post)qualitative research could become voguish and as a consequence, uncritically embraced in places (such as South Africa) removed from its sites of production. Therefore, it needs to be engaged with critically. The second reason why (post)qualitative research could have relevance to South Africa is because it resonates with many of the ethico-onto-epistemologies of Indigenous peoples. Put differently, (post)qualitative research resonates with values of Indigenous peoples such as Ubuntu (in the southern African context) and similar values in the broader Indigenous world. Some of the commonalities between (post)qualitative research and Indigenous beliefs are that: there is no separation between epistemology, ontology and axiology; the "non-human" has agential capacity; the human is embedded in/connected to a complex web of life; all modes of life are always inbecoming/unfolding, and so forth. These commonalities open up possibilities for productive collaborative research in new knowledge spaces between western (post)qualitative researchers 
and Indigenous researchers. Moreover, it opens up possibilities for Indigenous values to speak to the challenges of a contemporary world, as Le Grange $(2018 \mathrm{~b}, 52)$ writes in relation to Ubuntu:

"[T]here are commonalities between Ubuntu and contemporary (post)human thought, and in particular one strand of this thought, critical (post)humanism. Ubuntu might have emerged as a construct at a time when the world was less densely populated, when kinship networks were stronger and when people lived close to the land, but it can now also play a new role in a technology mediated world and inform thought that needs to be responsive to the Earth's rapid destruction ...."

But, a critical engagement with (post)qualitative research is also necessary. In relation to Ubuntu, for example, Le Grange (2018b) points out that there are also divergences between Ubuntu and certain strands of (post)humanism. There is no space to discuss the dissonances here (see Le Grange $2018 \mathrm{~b}$ for a detailed discussion). Suffice it to say, there could be divergences between (post)qualitative research and Indigenous values, depending on the (post)human theory/theories that inform(s) (post)qualitative research. Let, me stay with Ubuntu and point out one potential point of dissonance between Ubuntu and a particular take on (post)qualitative research. At the 2016 American Education Research American (AERA) conference in San Antonio, Elizabeth St Pierre stated that whenever she sees the word "social justice" in an article she stops reading it. ${ }^{6}$ There was not sufficient time in the discussion part of the session to engage St. Pierre but let us assume that she meant that social justice is a humancentred concept (a parochial idea) and that justice should be extended to all of life (the morethan-human world). If this assumption is correct then there would be a point of dissonance between St. Pierre's take on (post)qualitative research and Ubuntu. Ubuntu (relationality among humans) is a microcosm of Ukama (relatedness of everything in the cosmos). Ubuntu therefore does not jettison social justice, but it encompasses the idea that social justice is a "slice" of a broader justice (if justice is the appropriate word to use) towards the more-than-human world. In other words, even though Ubuntu is aligned with the idea that subjectivity is ecological it recognises the ethico-distinctiveness of the human being - that relationality with other human beings and relationality with the more-than-human world are not mutually exclusive (for a detailed discussion see Le Grange 2012).

Furthermore, Wu et.al. (2018) offer a different critique of (post)qualitative research. The authors argue that if there are points of resonance (and they suggest that there are) between (post)qualitative research and Indigenous philosophies then (post)qualitative research should pay homage to such Indigenous philosophies. They argue that if homage is not paid to philosophies such as Taoism and Ubuntu then these would be relegated to the margins and 
(post)qualitative research would remain a construct of the west (the Global North). (Post)qualitative research therefore needs to embrace Indigenous philosophies. As Wu et.al. $(2018,516)$ write:

"Taoism and Ubuntu as marginalised forms of knowledge call us to move beyond an obsession with western theoretical canons, question the inter-linkage of knowledge, power, and geopolitics, and acknowledge the need to bring indigenous philoso-praxis to the spotlight in order to transform our intellectual one-sidedness in 'west as method'."

The discussion on the second reason, makes the relevance of engaging (post)qualitative research in South Africa (and elsewhere) is clearly evident. This brings us to a brief discussion of the third reason why qualitative research could relevant to South Africa. (Post)qualitative research could be relevant to South Africa, because it could open up new ways of doing research in relation to challenging issues facing the country such as the water crisis in Cape Town ${ }^{7}$ and the land issue. ${ }^{8}$ (Post)qualitative research informed by (post)humanism and indigenous philosophies enables us to understand that water and land have agential capacities - they act and those acts have real effects. Therefore, in research processes we should respect water and land (and all modes of life), and be open to what water and land teaches us. Land is not a stage on which research is conducted but is imbricated in research - we come to know through research in intra-action with water and the land. Ulmer (2017) points out that (post)qualitative research invites us to think without, think with and to think differently. Thinking without is akin to non-representational research whereby by notions such as "representation, method, proper names, labels, and perhaps even methodology" (Ulmer 2017, 841) are removed or suspended from research processes. When this happens then researchers are free to embark upon imaginative adventures. Thinking with means that researchers think with water and with land (in this instance) instead of thinking about water and land and doing things to water and land. Such thinking could open up new ways of doing research through creative experiments with water and land. Thinking differently invites alternatives to methodological orthodoxy (Ulmer $2017,842)$ and conventional ways of knowing. Concerning the latter, Law $(2004,3)$ identifies four alternative ways of knowing: knowing as embodiment, knowing as emotionality and apprehension, knowing through deliberate imprecision, and knowing as situated enquiry. Knowing as embodiment is to know through the hungers, tastes, discomforts, or pains of our bodies. Knowing as emotionality is about opening us to worlds of sensibilities, passions, intuitions, fears and betrayals. Knowing through deliberate imprecision is about rethinking our ideas about clarity and rigour, and about finding ways of knowing the indistinct and slippery without trying to hold them tightly. Moreover, knowing as situated enquiry is about rethinking 
how far knowledge is able to travel and whether it still makes sense in other locations. These alternative ways of knowing register possibilities of doing research with water and land differently, that embraces the both social and ecological justice. Much more can be said about the relevance of (post)qualitative to South Africa and the conversation needs to continue.

\section{SOME PARTING THOUGHTS}

This article is not been aimed at those who have engaged with (post)qualitative research for some time, at those "who live and breathe (post)humanism" (Ulmer 2017, 833), but to those who might be beginning to engage with (post)qualitative research and to those who have not yet engaged with (post)qualitative research, in view of the fact that empirical research in South African higher education remains dominated by conventional quantitative and qualitative studies. The (post)human turn has "radically-and-rapidly-shifted" (Ulmer 2017, 832) what is possible in research, research that falls under an umbrella term (post)qualitative research. I have described some of the emerging characteristics of (post)qualitative research and discussed the potential relevance of (post)qualitative inquiries to South Africa. I have not provided a set of answers in the article, but have opened up possibilities for new ways of doing research in South Africa (and elsewhere) in the Anthropocene and at a time when there is much discussion in the country about decolonisation and decoloniality.

\section{NOTES}

1. I use parenthesis to indicate that although (post)qualitative research represents a philosophical shift from qualitative research, the data produced in empirical studies labelled (post)qualitative, will be in the form of words and visual images, which are qualitative.

2. Morton (quoted in Payne 2016, 169) states that the Anthropocene is a peculiar term for some because in this epoch "non-humans make decisive contact with humans".

3. The brief USA context sketched, resonates with experiences in other contexts. In South Africa, for example, templates for applying for research grants (whether institutional or national) have become standardised and biased towards research in the natural sciences or neo-positivist research in the social sciences.

4. St Pierre $(2013,648)$ points out that there have been powerful critiques of epistemological projects in which issues have been raised such as "what counts as knowledge and whose knowledge counts, how knowledge becomes foundational and is used to secure, the imbrication of knowledge and relations of power, the links between knowledge and ethics, how knowledge produces reality, and so on". Knowledge is also the focus in decolonial literature produced in the global south. For example, Santos (2014) coins the term "epistemicide" to depict the decimation or murder of knowledge brought about through an unequal exchange of cultures as a consequence of colonialism.

5. Lastly, has reference to this article. There can be no end or closure to (post)qualitative research it is always in-becoming.

6. I can't recall what the paper was that St. Pierre read when she made the remark, but it was in one of the sessions on (post)qualitative research. 
7. South Africa is a water scarce country and climate change is exacerbating the problem. The recent drought in the city of Cape Town almost resulted in the city being the first one in the world to run out of water. Fortunately, Day Zero (the day the city would be without water) was averted due lower consumption and relatively good rains received in the winter of 2018.

8. During colonialism and apartheid indigenous peoples were forcefully removed from land that they inhabited through racist laws. The land restitution processes put in place in post-apartheid has largely been a failure. Currently, the majority of the land in South Africa is still owned by a minority white population. The land question therefore remains unresolved.

\section{REFERENCES}

Barad, K. 2007. Meeting the universe halfway: Quantum physics and the entanglement of matter and meaning. Durham, NC: Duke University Press.

Brady, H. and D. Collier. (Eds.). 2004. Rethinking social inquiry: Diverse tools, shared standards. Lanham, MD: Rowman and Littlefield.

Braidotti, R. 2006. Transpositions. Malden, MA: Polity Press.

Braidotti, R. 2012. Afterword: Complexity, materialism, difference. Angelaki 17: 169-176.

Braidotti, R. 2013. The posthuman. Malden, MA: The Polity Press.

Byrant, L., N. Srnicek and G. Harman. 2011. Towards a speculative philosophy. In The speculative turn: Continental materialism and realism, ed. L. Byrant, N. Srnicek and G. Harman. Melbourne: re.press.

Deleuze, G. 2000. Proust \& signs: The complete text. Translated by R. Howard. Minneapolis, MN: University of Minnesota Press. (Originally published in 1964.)

Deleuze, G. and F. Guattari. 1987. A thousand plateaus: Capitalism and schizophrenia, translated by B. Massumi. Minneapolis: University of Minnesota Press.

Denzin, N. K. and Y. S. Lincoln. 2008. Introduction: The discipline and practice of qualitative research. In The landscape of qualitative research, ed. N. K. Denzin and Y. S. Lincoln. Third Edition. London: Sage.

Gage, N. 1989. The paradigm wars and their aftermath: A "historical" sketch of research on teaching since 1989. Teachers College Record 91(2): 135-150.

Giddens, A. 1976. New rules of sociological method. London: Hutchinson and Company.

Gough, N. 2016. Postparadigmatic materialisms: A "new movement of thought" for outdoor environmental education research? Journal of Outdoor and Environmental Education 19(2): 5165.

Guattari, F. 2001. The three ecologies. Translated by Ian Pindar and P. Patton. London: The Athlone Press.

Howe, K. 1992. Getting over the quantitative-qualitative debate. American Journal of Education 100(2): 236-256.

Ingold, T. 2015. In Non-representational methodologies: Re-visioning research, ed. P. Vannini. Foreword. London: Routledge.

Johnson, J. (Ed.). 2013. Dark trajectories: Politics of the outside. Hong Kong, China.

Lather, P. 2013. Methodology-21: What do we do in the afterward? International Journal of Qualitative Studies in Education 26(6): 634-645.

Lather, P. and E. St. Pierre. 2013. Introduction: Post-qualitative research. International Journal of Qualitative Studies in Education 26(6): 629-633.

Le Grange, L. 2000. Is qualitative research a meaningful term for describing the cross-fertilisation of ideas which characterises contemporary educational research? South African Journal of Education 20(3): 192-195. 
Le Grange, L. 2012. Ubuntu, ukama, environment and moral education. Journal of Moral Education 41(3): 329-340.

Le Grange, L. 2016. Sustainability education and (curriculum) improvisation. Southern African Journal of Environmental Education 32: 26-36.

Le Grange, L. 2017. Environmental education after sustainability. In Post-sustainability: Remaking education for the future, eds. B. Jickling and S. Sterling. New York: PalgraveMacMillan.

Le Grange, L. 2018a. Spinoza, deep ecology and education informed by a (post)human sensibility. Educational Philosophy and Theory 50(9): 878-887.

Le Grange, L. 2018b. The notion of Ubuntu and the (post)humanist condition. In Indigenous philosophies of education around the world, eds. J. Petrovic and R. Mitchell. New York: Routledge.

Meillassoux, Q. 2008. After finitude: An essay on the necessity of contingency, translated by R. Brassier. Continuum: New York.

Payne, P. G. 2016. What next? Post-critical materialisms in environmental education. Journal of Environmental Education 47(2): 169-178.

Santos, B. 2014. Epistemologies of the south: Justice against epistemicide. Boulder: Paradigm Publishers.

Smith, D. W. 2012. Essays on Deleuze. Edinburgh: Edinburgh University Press.

St. Pierre, E. A. 2011. Post-qualitative research: The critique and the coming after. In The Sage handbook of qualitative research, ed. N. K. Denzin and Y. S Lincoln. Fourth Edition. Thousand Oaks, CA: Sage publishers.

St. Pierre, E. A. 2013. The posts continue: Becoming. International Journal of Qualitative Studies in Education 26(6): 646-657.

Ulmer, J. B. 2017. Posthumanism as research methodology: Inquiry in the Anthropocene. International Journal of Qualitative Research in Education 30(9): 832-848.

Wu, J., P. W. Eaton, D. W. Robinson-Morris, M. F. G. Wallace and S. Han. 2018. Perturbing possibilities in the postqualitative turn: Lessons from Taoism and Ubuntu. International Journal of Qualitative Studies in Education 31(6): 504-519. 